\title{
To what extent does a tobacco carve-out protect public health in the Trans-Pacific Partnership Agreement?
}

\author{
Katherine Hirono a,d, Deborah Gleeson ${ }^{\mathrm{b}}$ and Becky Freemanc \\ a Centre for Health Equity Training, Research and Evaluation, University of New South Wales, a member of the Ingham Institute, \\ Sydney, Australia \\ b School of Psychology and Public Health, La Trobe University, Melbourne, Victoria, Australia \\ c School of Public Health, University of Sydney, NSW, Australia \\ d Corresponding author: k.hirono@unsw.edu.au
}

\section{Article history}

Publication date: April 2016

Citation: Hirono K, Gleeson D,

Freeman B. To what extent does a tobacco carve-out protect public health in the Trans-Pacific Partnership Agreement? Public Health Res Pract. 2016;26(2):e2621622. doi: http:// dx.doi.org/10.17061/phrp2621622

\section{Introduction}

In November 2015, following more than 5 years of negotiations, the text of the Trans-Pacific Partnership Agreement (TPP) was released. The TPP, which includes 12 Pacific Rim nations - Australia, Brunei, Canada, Chile, Japan, Malaysia, Mexico, New Zealand, Peru, Singapore, Vietnam and the US - is the largest regional trade agreement concluded to date. Participating countries constitute more than $36 \%$ of global gross domestic product and more than $25 \%$ of global trade. ${ }^{1}$ During the negotiations, advocates voiced concerns about the potential effect of the TPP on many areas of public health, including the cost of medicines and the ability to effectively regulate alcohol, tobacco and processed foods. ${ }^{2}$ Of primary concern was the inclusion of an investor-state dispute settlement (ISDS) mechanism within the TPP that allows foreign companies to sue governments outside of the domestic court system if they believe their investor rights have been violated. This fear is not without substance, as tobacco companies have a history of using international investment rules to obstruct policies that constrain tobacco marketing. ${ }^{3}$

\section{The 'win' for tobacco control}

A development welcomed by public health advocates in the final stages of the TPP negotiations was an exclusion (or carve-out) of tobacco control from the ISDS mechanism. Article 29.5, 'Tobacco control measures', sets out how TPP countries may elect to deny the use of the ISDS mechanism for claims applying to tobacco control measures. ${ }^{4}$ According to Article 29.5, a party may deny the use of ISDS at any time, meaning a country can elect to carve out tobacco control now or at any time once a claim has been brought forward. For countries that choose to use it, the carve-out for tobacco control will prevent tobacco companies from using ISDS to attack domestic policies that aim to decrease tobacco use, such as plain packaging. Yet despite these important wins, the tobacco control carve-out has limitations, and substantial risks remain for other important public health policies. 


\section{Limitations and loopholes}

In August 2013, Malaysia tabled a proposal to completely carve out tobacco from the TPP. ${ }^{5}$ The final TPP tobacco carve-out is much more limited in scope.

First, without a complete carve-out, other TPP provisions could be used by the tobacco industry to exert undue influence. Concerns have been raised about the potential effect of many TPP provisions on the implementation of the World Health Organization Framework Convention on Tobacco Control - such as the ability to restrict tobacco advertising and marketing, the use of trademarks on packaging, and the participation of the industry in policy making. ${ }^{2,6}$ The full text of the final TPP requires close scrutiny to identify potential effects on tobacco control.

Second, allowing parties to 'elect' to deny the use of ISDS means that the carve-out is optional. The tobacco carve-out was strongly opposed by tobacco companies, business associations and politicians from tobacco-growing US states during the negotiations. ${ }^{7}$ The ratification of the TPP in the US may depend on the support of members of Congress who are opposed to the carve-out. ${ }^{8}$ In this context, governments may come under pressure to not use the safeguard.

Third, it does not apply to the state-to-state dispute settlement process in which one TPP country may challenge measures introduced by another. Australia is already facing disputes brought by four countries (Cuba, Dominican Republic, Honduras and Indonesia) over tobacco plain packaging laws using the stateto-state dispute settlement mechanisms of the World Trade Organization. ${ }^{9}$

Fourth, the ISDS safeguard in the 'Exceptions and general provisions' chapter only applies to "manufactured tobacco products (including products made or derived from tobacco)". ${ }^{4}$ Tobacco leaf is not excluded and will be treated like other agricultural products under the TPP (for example, it may be eligible for tariff reductions). While nicotine products derived from tobacco are covered by the carve-out, it is unclear what the implications will be for future regulation of e-cigarettes, given that not all e-cigarettes contain nicotine.

Another critical issue is that, despite the inclusion of legal safeguards in some parts of the TPP text, other essential public health and environmental measures such as efforts to address climate change or reduce alcohol consumption - are not exempt from ISDS challenges. A far preferable approach would be to exclude ISDS from trade agreements altogether, or at least to include a concrete carve-out for all public health and environmental measures.

\section{Conclusion}

The ISDS carve-out for tobacco is undoubtedly a victory for tobacco control. This may help to set precedents for future trade agreements. Yet the failure of the TPP to include a mandatory, comprehensive carve-out of tobacco leaves other trade avenues vulnerable to tobacco industry exploitation. Without comprehensive exclusions for tobacco, the TPP leaves open the risk that the Australian and other governments will face barriers to protecting their citizens from smoking harms. Without exclusions for other public health and environmental measures, ISDS remains a risk for public health.

The TPP was signed in February 2016 but is yet to be ratified. The text cannot be changed, but parliaments in TPP countries must carefully consider the consequences of ratifying an agreement with limited safeguards for public health. At the very least, lessons should be drawn from this experience to inform negotiations for future trade agreements.

\section{Competing interests}

DG has received funding from national and international non-government organisations to attend speaking engagements related to trade agreements and health, including the TPP, and has represented the Public Health Association of Australia on matters related to the TPP.

\section{Author contributions}

$\mathrm{KH}$ designed, drafted and edited the paper. DG contributed to the drafting and editing. BF edited the paper.

\section{References}

1. Department of Foreign Affairs and Trade. Trans-Pacific Partnership Agreement. Canberra: Department of Foreign Affairs and Trade; 2016 [cited 2016 Mar 2]. Available from: dfat.gov.au/trade/agreements/tpp/Pages/transpacific-partnership-agreement-tpp.aspx

2. Hirono K, Haigh F, Gleeson D, Harris P, Thow AM. Negotiating healthy trade in Australia: health impact assessment of the proposed Trans-Pacific Partnership Agreement. Sydney: Centre for Health Equity Training Research and Evaluation, University of NSW; 2015 [cited 2016 Mar 2]. Available from: hiaconnect.edu.au/wpcontent/uploads/2015/03/TPP_HIA.pdf

3. Porterfield MC, Byrnes CR. Philip Morris v. Uruguay: will investor-state arbitration send restrictions on tobacco marketing up in smoke? Investment Treaty News. 2011 Jul 12 [cited 2016 Feb 23]. Available from: www.iisd.org/ itn/2011/07/12/philip-morris-v-uruguay-will-investor-statearbitration-send-restrictions-on-tobacco-marketing-up-insmoke 
4. New Zealand Ministry of Foreign Affairs and Trade. Text of the Trans-Pacific Partnership Agreement. Wellington: Ministry of Foreign Affairs and Trade; 2015 [cited 2015 Nov 17]. Available from: mfat.govt.nz/Treatiesand-International-Law/01-Treaties-for-which-NZ-isDepositary/0-Trans-Pacific-Partnership-Text.php

5. Malaysia Ministry of International Trade and Industry. Response to the statement issued by Malaysian Council for Tobacco Control (MCTC) on the proposal for full tobacco control carve-out under TPPA. Kuala Lumpur: MITI; 2015 [cited 2016 Feb 23]. Available from: fta.miti. gov.my/index.php/pages/view/281

6. Mitchell AD, Voon TSL, Whittle D. Public Health and the Trans-Pacific Partnership Agreement. Asian Journal of International Law. 2014;5(2):279-309. Available from: papers.ssrn.com/sol3/papers. cfm?abstract_id=2393670
7. Needham V. Tobacco 'carve-out' sparks bid to sink TPP. The Hill. 2015 Oct 8 [cited 2016 Feb 25]. Available from: thehill.com/policy/finance/256311-tobacco-carve-outsparks-bid-to-sink-tpp

8. Kane P, Nakamura D. McConnell warns that trade deal can't pass Congress before 2016 elections. The Washington Post. 2015 Dec 10 [cited 2016 Feb 25]. Available from: www.washingtonpost.com/politics/ mcconnell-warns-that-trade-deal-cant-pass-congressbefore-2016-elections/2015/12/10/b8151f26-9f66-11e58728-1af6af208198_story.html

9. Australian Department of Foreign Affairs and Trade. WTO disputes - tobacco plain packaging. Canberra: DFAT; 2015 [cited 2015 Nov 26]. Available from: dfat.gov.au/ international-relations/international-organisations/wto/wtodispute-settlement/Pages/wto-disputes-tobacco-plainpackaging.aspx

\section{Copyright: (c) (i) (2)}

(C) 2016 Hirono et al. This article is licensed under the Creative Commons Attribution-NonCommercial-ShareAlike 4.0 International Licence, which allows others to redistribute, adapt and share this work non-commercially provided they attribute the work and any adapted version of it is distributed under the same Creative Commons licence terms. See: www.creativecommons.org/licenses/by-nc-sa/4.0/ 